\title{
MORPHOLOGICAL STUDY OF SUBMANDIBULAR SALIVARY GLAND IN FOETUS OF VARING AGE
}

\section{Nedunchezhiyan Selvarasu ${ }^{1}$, Muthu Prasad Puthuraj ${ }^{* 2}$.}

${ }^{1}$ Assistant Professor, Department of Anatomy, K.A.P.Viswanatham Government Medical College, Colletor's office Road, Periyamilaguparai, Tiruchirappalli, Tamil Nadu 620001, India.

${ }^{*}$ Senior Assistant Professor, Department of Anatomy, K.A.P.V iswanatham Government Medical College, Colletor's office Road, Periyamilaguparai, Tiruchirappalli, Tamil Nadu 620001, India.

\section{ABSTRACT}

Background: The morphological study of foetal submandibular gland has been the subject of much investigation in recent years. Throughout the foetal life the submandibular salivary gland progressively increases in size and weight due to ductal proliferation, increased in lobulation and connective tissue septa. The relation of the mylohyoid muscle with respect to the submandibular salivary gland proves to be vital one during surgeries of the submandibular region.

Materials and Methods: A total of 30 fetuses ranging from 10 weeks of gestation to full term were divided into three groups viz., Group I [10-16 weeks] , Group II [18-25weeks], Group III[ 28weeks - full term] and they are dissected and subjected to morphological study.

Results: The shape of the gland in Group I - Global ; Group II - Ovoid ; Group III - Irregular. There was no obvious lobes and interlobular fissure in Group I ; Interlobular fissure appears in Group II ; well differentiated fissure in GroupIII. Weight and Dimentions of the gland increases from group I to group III. Mylohyoid muscle was seen just behind the Gland in group I ; just enters the interlobular fissure in Group II ; occupies the half of the fissure in Group III.

Conclusion: The knowledge of morphological features and relations of the developing submandibular salivary gland contribute to future studies in dental surgery, fetopathology, perinatology and in radiadiagnosis KEY WORDS: Foetus, Submandibular Gland, Morphology, Mylohyoid Muscle, Digastric Triangle.

Address for Correspondence: Dr. Muthu Prasad Puthuraj, Assistant Professor, Department of Anatomy, K.A.P.Viswanatham Government Medical College, Colletor's office Road, Periyamilaguparai, Tiruchirappalli, Tamil Nadu 620001, India. E-Mail: prasadmuthu@yahoo.com

Access this Article online Quick Response code

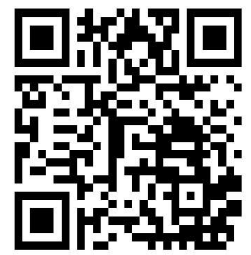

DOI: $10.16965 /$ ijar.2018.195

Journal Information

International Journal of Anatomy and Research

ICV for 2016 ISSN (E) 2321-4287 | ISSN (P) 2321-8967

https://www.ijmhr.org/ijar.htm

DOI-Prefix: https://dx.doi.org/10.16965/ijar

\section{Article Information}

Received: 22 Mar 2018

Peer Review: 23 Mar 2018

Revised: None
Accepted: 08 May 2018

Published (0): 05 Jun2018

Published (P): 05 Jun 2018

\section{INTRODUCTION}

The paired submandibular glands which is also known as submaxillary glands are major salivary glands located beneath the floor of the mouth. They each weigh about 15 grams and contribute some $60-67 \%$ of unstimulated saliva secretion but on stimulation their contribution decreases in propotion.
Located in the anterior part of the Submandibular triangle their secretions are being delivered into the floor of the mouth through WHARTON'S duct.

The submandibular glands are a pair of elongated, flattened hooks which have two sets of arms superficial and deep. The positioning of these arms is in relation to the Mylohyoid 
muscle, which the gland hooks around[1].

The submandibular salivary glands develop late in the sixth week of prenatal development. They develop bilaterally from epithelial buds in the sulcus surrounding the sublingual folds on the floor of the primitive mouth. Solid cords branch from the buds and grow posteriorly, lateral to the developing tongue. The cords of the submandibular gland later branch further and then become canalized to form the ductal part. The submandibular gland acini develop from the cords with rounded terminal ends at 12 weeks, and secretory activity via the submandibular duct begins at 16 weeks. Growth of the submandibular gland continues after birth with the formation of more acini. Lateral to both sides of the tongue, a linear groove develops and closes over to form the submandibular duct[2,3].

\section{MATERIALS AND METHODS}

A total number of 30 normal human fetuses ranging from 10 weeks to full term were collected for the study from the Department of Obstetrics and Gynaecology KAPV Government medical college, Trichy.(fig.1)

The fetuses ranging from 10 weeks of gestation to full term were divided into 3 groups, 10 in each group viz., Group I [10-16 weeks], Group II [18-25 weeks], and Group III [28 weeks - full term]. The collected foetuses were weighed using digital weighing balance and also the gestational ages were confirmed by measuring crown rump length using the inch tape. The fetuses were examined for the presence of any anomalies and fixed in $10 \%$ formalin for ten days and submandibular region was slit open and the right and left submandibular salivary glands were dissected out (fig.2).

Plan of the study:

Following parameters were taken in to consideration for the study and the readings were tabulated.

\section{MORPHOLOGICAL PARAMETERS}

Dimensions of the digastric triangle: Anterior limb (anterior belly of digastric muscle), posterior limb (posterior belly of digastric muscle) and base (length of base of the mandible + imaginary line between angle of mandible and mastoid process) were measured by using divider.

Dimensions of the gland: Length (I), breath (b), and thickness $(t)$ were measured by using digital vernier caliper.

Weight of the gland: Weight (wt) was measured using digital weighing balance

Shape of the gland: The shape was observed and noted by naked eye examinations.

\section{OBSERVATION AND RESULTS}

Table 1: Average dimensions of submandibular salivary gland (group I).

\begin{tabular}{|c|c|c|c|c|}
\hline $\begin{array}{c}\text { Salivary } \\
\text { glands }\end{array}$ & $\begin{array}{c}\text { Length } \\
(\mathrm{mm})\end{array}$ & $\begin{array}{c}\text { Breadth } \\
(\mathrm{mm})\end{array}$ & $\begin{array}{c}\text { Thickness } \\
(\mathrm{mm})\end{array}$ & $\begin{array}{c}\text { Weight } \\
(\mathrm{mg})\end{array}$ \\
\hline Right & 8.9 & 6 & 4.2 & 24 \\
\hline Left & 8.8 & 5.8 & 4 & 23 \\
\hline Average & 8.85 & 5.9 & 4.1 & 23.5 \\
\hline
\end{tabular}

Table 2: Average dimensions of submandibular salivary gland (group II).

\begin{tabular}{|c|c|c|c|c|}
\hline $\begin{array}{c}\text { Salivary } \\
\text { glands }\end{array}$ & $\begin{array}{c}\text { Length } \\
(\mathrm{m})\end{array}$ & $\begin{array}{c}\text { Breadth } \\
(\mathrm{mm})\end{array}$ & $\begin{array}{c}\text { Thickness } \\
(\mathrm{mm})\end{array}$ & $\begin{array}{c}\text { Weight } \\
(\mathrm{mg})\end{array}$ \\
\hline Right & 14.8 & 8.9 & 6.6 & 56 \\
\hline Left & 14.5 & 8.7 & 6.6 & 53.2 \\
\hline Average & 14.65 & 8.8 & 6.6 & 54.6 \\
\hline
\end{tabular}

Table 3: Average dimensions of submandibular gland (group III).

\begin{tabular}{|c|c|c|c|c|}
\hline $\begin{array}{c}\text { Salivary } \\
\text { glands }\end{array}$ & $\begin{array}{c}\text { Length } \\
(\mathrm{mm})\end{array}$ & $\begin{array}{c}\text { Breadth } \\
(\mathrm{mm})\end{array}$ & $\begin{array}{c}\text { Thickness } \\
(\mathrm{mm})\end{array}$ & $\begin{array}{c}\text { Weight } \\
(\mathrm{mg})\end{array}$ \\
\hline Right & 17.2 & 12.5 & 8.2 & 111 \\
\hline Left & 16.6 & 11.2 & 8 & 108.5 \\
\hline Average & 16.9 & 11.5 & 8.1 & 109.7 \\
\hline
\end{tabular}

Table 4: Morphological correlations between three groups.

\begin{tabular}{|c|c|c|c|c|}
\hline Salivary glands & $\begin{array}{c}\text { Length } \\
(\mathrm{mm})\end{array}$ & $\begin{array}{c}\text { Breadth } \\
(\mathrm{mm})\end{array}$ & $\begin{array}{c}\text { Thickness } \\
(\mathrm{mm})\end{array}$ & $\begin{array}{c}\text { Weight } \\
(\mathrm{mg})\end{array}$ \\
\hline Group I average & 8.85 & 5.9 & 4.1 & 23.5 \\
\hline Group II average & 14.65 & 8.8 & 6.6 & 54.6 \\
\hline Group III average & 16.9 & 11.5 & 8.1 & 109.7 \\
\hline
\end{tabular}

Fig. 1: Collected fetal specimens.

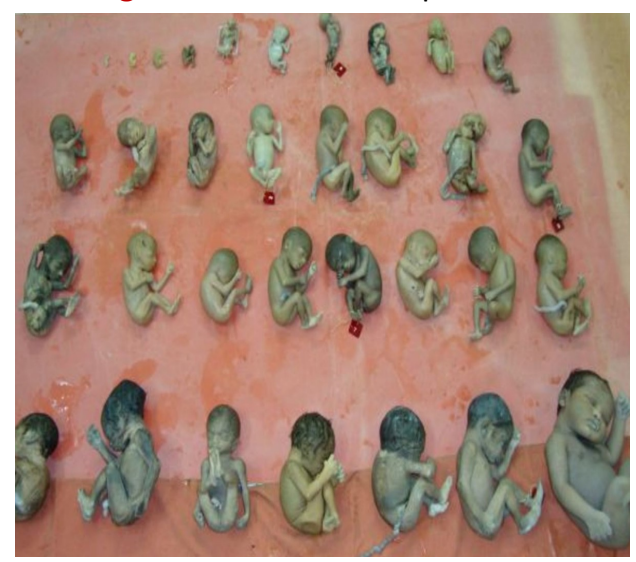


Fig. 2: Dissected foetus showing submandibular salivary gland and digastric triangle.

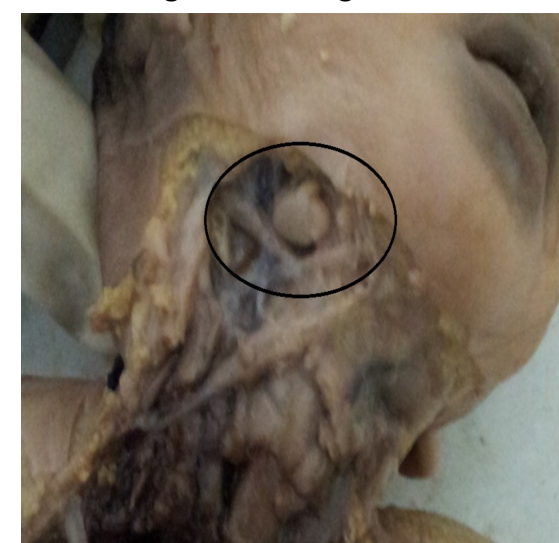

Fig. 3: Submandibular salivary gland and digastrics triangle - group II.

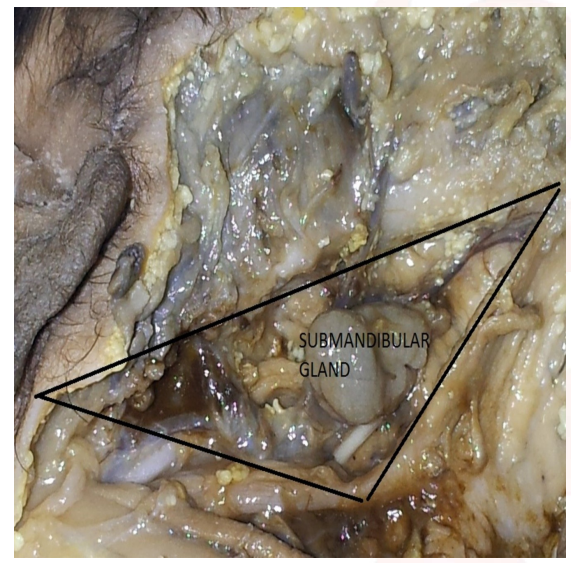

Fig. 4: Submandibular salivary gland and mylohyoid muscle - group III.

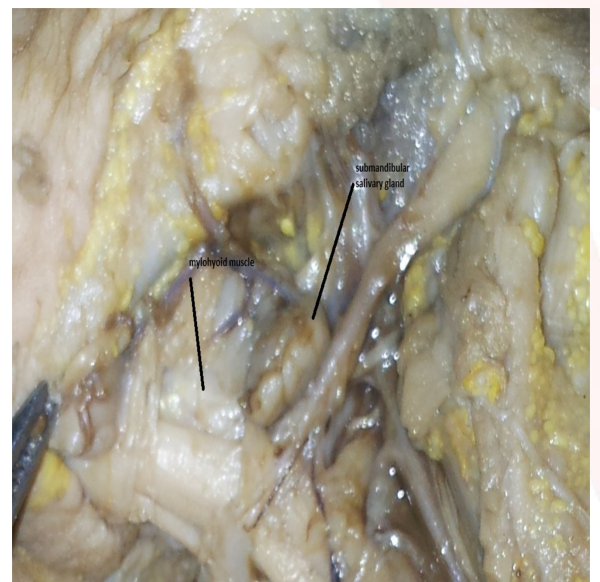

Fig. 5: Submandibular salivary gland and lingual nerve - group II.

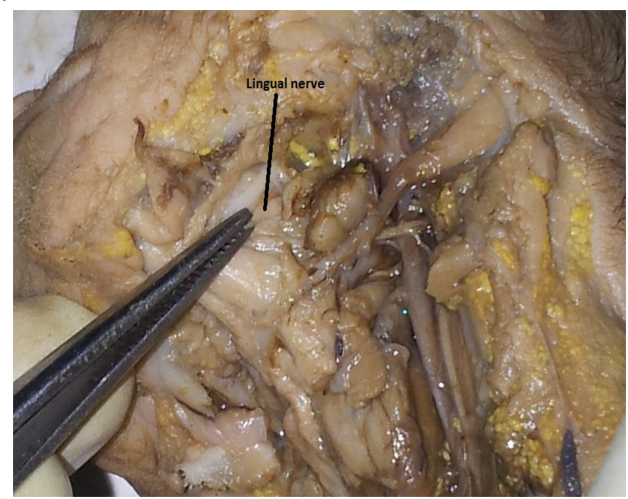

Fig. 6: Submandibular salivary gland and mylohyoid muscle - group III.

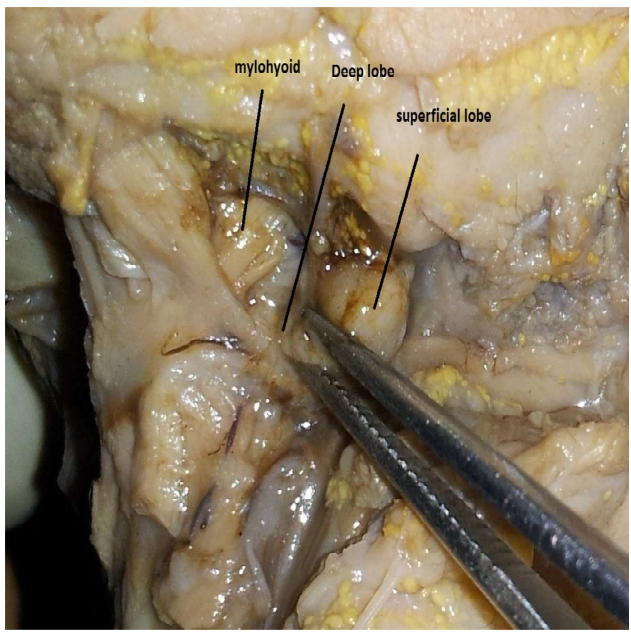

Fig. 7: Submandibular salivary gland and lingual nerve - group III.

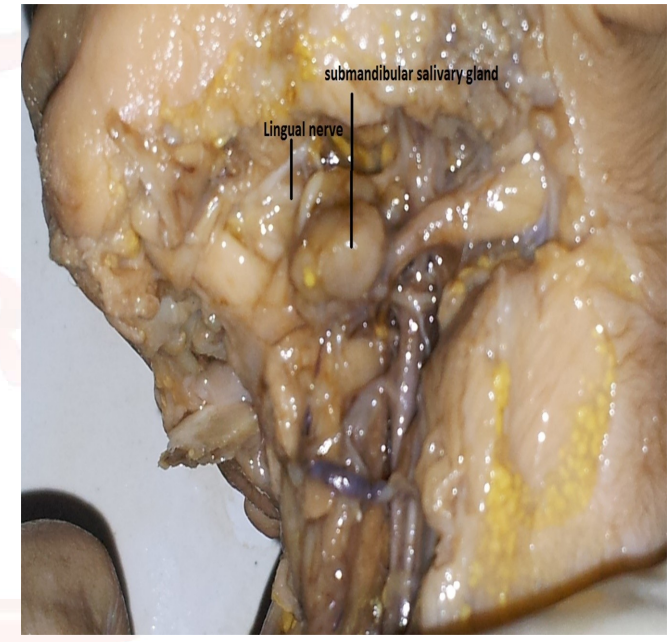

Fig. 8: Submandibular salivary gland and facial artery group III.

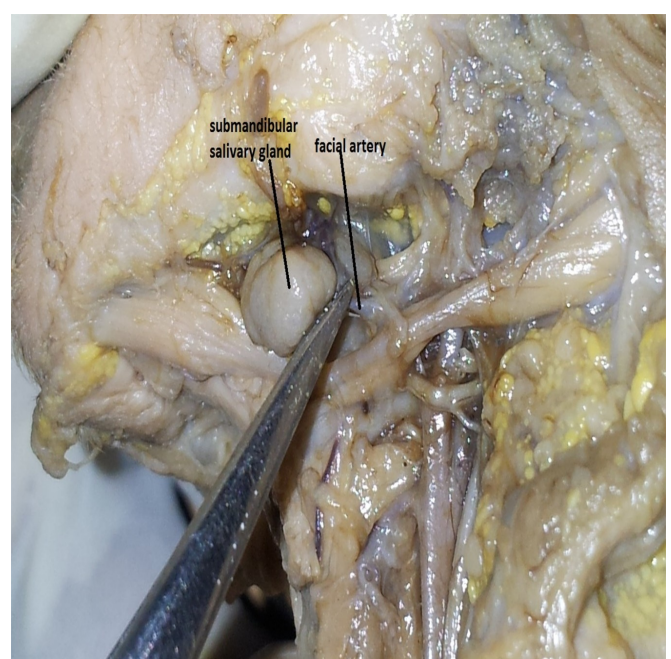

The study included a total number of thirty foetuses, ten from each groups. From these the submandibular salivary glands were dissected and dimensions like length, breadth, thickness and weight were measured. These data were tabulated and analyzed. 
Group - I: The glands were located in the anterior aspect of digastric triangle. The analysis showed that there was no definite variation in the shape of the right and left submandibular salivary glands. On comparison, the right and the left submandibular salivary glands showed that, the right is heavier than the left and also greater in diameter (table 1 \& bar dig.1), despite this there is no significant variation in the dimensions of the digastric triangle.

The gland is globular in shape without two parts at $10^{\text {th }}$ week (fig.8), as it is devoid of the fissure that separates the gland as superficial and deep, interlobular fissure start to appear at $14^{\text {th }}$ week of gestation. The gland is located just behind the mylohyoid muscle. The lingual nerve is found to be medial to the gland. The facial artery is seen posterior to the gland.

Group 2: Both the right and left submandibular glands occupied the middle of the digastric triangle (fig.3). The shape of both the glands becomes irregular in this group. Similar to the previous group, the right submandibular gland is heavier than the left and the diameter greater than the left (table $2 \&$ bar dig. 2) with no significant variation in the dimensions of the digastric triangle.

When compared to group 1 the dimensions of the glands increased around 1.6 times and weight increased around 2.3 times.

The 18th week gland had lobar division also with 2 major lobes and many small lobules; the gland has lobular divisions and two major lobes i.e. superficial and deep. The mylohyoid muscles just enter in to the interlobular fissure (fig. 4). Lingual nerve was slightly higher in the medial aspect of the gland (fig. 5). Facial artery was found close to the posterior aspect of the gland.

Group 3: In this group too, the shape of the glands was irregular with no significant variations between the right and left salivary glands, the right gland heavier than the left as well as the diameter greater than the left gland (table $3 \&$ bar dig. 3). There is no significant variation in the dimensions of the digastrics triangle between the two sides.

When compared to group 1 diameter of the glands increased about 1.9 times, against group 2 it is increased by 1.15 times. On comparing weight, against group 1 is increased by 4.6 times, against group 2.3 times (table 4 \& bar diag. 4). The depth of the Interlobular fissure is increased the superficial and deep lobes of the gland are clearly visualised. Mylohyoid muscle occupies the half of the interlobular fissure (fig.6). Lingual nerve found to be superomedial to the gland (fig.7). Facial artery is in contact with the posterior aspect of the gland (fig.8)

\section{DISCUSSION}

The present study included a total number of thirty foetuses, ten from each groups (I, II, III). From these, the submandibular salivary glands were dissected and dimensions like length, breadth, thickness and weight were all measured along with the histological features and shape of the gland were also analysed.

Shape: The mere observation of bazan et al (2001) in the gerbil was found to be ovoid in shape. In the present study the submandibular glands of human foetuses, the shape of the glands were found to be globular, ovoid and irregular in the groups I, II, III respectively [4].

Dimensions: The average dimension of the submandibular glands of various group are shown in the table 4 , and were similar to the findings of the SIVAKUMAR et al (2003). The measurement of the dimensions were found to be, Group I-8.9mm in length, $5.7 \mathrm{~mm}$ in breadth and $4 \mathrm{~mm}$ in thickness. Group II $14.9 \mathrm{~mm}$ in length, $9 \mathrm{~mm}$ in breadth and $6.5 \mathrm{~mm}$ in thickness, Group III $16.8 \mathrm{~mm}$ in length, $11.5 \mathrm{~mm}$ in breadth and 8.1 in thickness. In group III when compared to group I the diameter of the glands increased about 1.9times, against group II it is increased by 1.15 times. The comparison of the dimensions of present study with the Sivakumar et al study corroborates that the findings of both the studies are similar [5].

Weight: the weights of submandibular glands of group I, II \& III were $23.5 \mathrm{mg}, 54.6 \mathrm{mg} \&$ $109.7 \mathrm{mg}$ respectively. In group III when comparing against group I it was increased by 4.6 times, against group II by 2.3 times, and the right side of the gland was little heavier than the left side. Bojan Stimec et al (2006) analytical study of morphometric parameters of submandibular salivary glands showed no significant differences between the right and left glands. It also 
showed a high level right-left symmetry in the linear morphometric parameters, but in the present study it showed that the right submandibular gland was little larger than the left submandibular salivary gland [6].

The increase in ductal proliferation, lobulation and connective tissue septa formation caused an increase in the size and weight of the gland from 12 weeks to full term (table.4).This result is same as that of Sivakumar et al (2003) study[5].

H. Fernandez Garcia et al (2002) study reported that in rats, the size of the submandibular salivary gland differs between the sexes. The size of the gland is little bigger in the male than in the female. The same findings were observed in the present study[7].

Merida Velasco et al (1993) ) reported that during the early fetal period (weeks 9 and 10 of development), the submandibular gland began to branch into lobules, and grew to reach the posterior margin of the mylohyoid muscle. The observations of the present study is supported by the Merida Velasco et al(1993) study, as in the present study, in group I the gland was just behind the mylohyoid, group II the mylohyoid muscle just entering the interlobular fissure and in group III the muscle occupies half of the interlobular fissure[8].

Similar to the relation of the gland in this present study in all three groups of foetuses, the facial artery is located in the posterior aspect and the lingual nerve is placed superomedial to the gland as in adults. Hence the adult relations were the same in fetal group also except mylohyoid musle.

\section{CONCLUSION}

The present study was done to find out the changes that occurred in terms of morphology during the various changes of fetal life. The shape of the submandibular salivary gland, in the group I it was global, in group II ovoid and irregular in group III.

Morphologically there is no obvious lobes and interlobular fissure in group I. The interlobular fissure starts appearing in the group II and in group III the lobes are well differentiated. The dimensions of the gland increases proportion- ately, on comparing with group I it is increased about 1.9 times, against group 2 it is increased by 1.15 times. The weight of the submandibular gland increases proportionately with respect to the groups under study, it is $23.5 \mathrm{~g}$ in the group $\mathrm{I}$, in group II it increases by 2.32 times weighing $54.6 \mathrm{~g}$, the weight increases by 2.00 times and weighs $109.7 \mathrm{~g}$. On relating the mylohyoid muscle with the gland, it was seen just behind the gland in group I, in group II in just enters the interlobular fissure and it occupies half of the interlobular fissure. Similar to the adults lingual nerve is superomedial to the gland and facial artery is posterior to the gland in all the three groups.

Thus the present study may be useful for clinicians especially in understanding the normal pattern of the submandibular salivary gland development in fetal period and also to delineate any abnormal developmental problems. We believe that the results obtained from this study will be beneficial in understanding the development of submandibular salivary gland and also to contribute to future studies in dental surgery, fetopathology, perinatology and in radio diagnosis.

\section{Conflicts of Interests: None}

\section{REFERENCES}

[1]. Gray's Anatomy, 40th Edition, the Anatomical basis of clinical practice, pages 520-521.

[2]. Gibson, M.H. The prenatal human submandibular gland: a histological, histo-chemical and ultrastructural study. Anatomischer Anzeiger. 19883;153 (1):91-105

[3]. El - Mohandes, E.A; Botros, K.G; Bondok A.A. Prenatal development of the human submandibular gland. Acta Anatomica. 1987;130(3):213-218.

[4]. Ikpegbu E, Nlebedum UC, Nnadozie O, Agbakwuru IO. Microscopic study of the submandibular salivary gland of adult African giant pouched rat (Cricetomys gambianus, Waterhouse-1840). Iraqi Journal of Veterinary Science. 2013 Jan 1;27:85-9.

[5]. Sivakumar M, Sud M, Vathsala V. Histogenesis and morphometric study of human foetal submandibular salivary gland. J. Anat. Soc. India. 2003;52(1):36.

[6]. Bojan Stimec, Slobodan Nikolic, Zoran Rakocevic, Mirko Bulajic, 2006, Symmetry of the submandibular glands in humans-a postmortem study assessing the linear morphometric parameters, Oral Surgery, Oral Medicine, Oral Pathology, Oral Radiology, and Endodontology, 2006;102(3):391-394. 
[7]. H Fernandez Garcia et.al 2002:Histomorphometrical study of submandibular gland ductal system in the rats:Histo Histopathol 2002;17:813-816(7).

[8]. Merida - Velasco, J.A., Sanchez - Montesinos, I, Espin -Ferra, J, Garcia - Garcia, J.D, Garcia-Gomez, S, Roldan-Schilling, V. Development of the human submandibular salivary gland. Journal of Dental Research 1993;72(8):1227-1232.

How to cite this article:

Nedunchezhiyan Selvarasu, Muthu Prasad Puthuraj. MORPHOLOGICAL STUDY OF SUBMANDIBULAR SALIVARY GLAND IN FOETUS OF VARING AGE. Int J Anat Res 2018;6(2.3):5320-5325. DOI: 10.16965/ijar.2018.195 